Research Article, Issue 4
Analytical Methods in Environmental Chemistry Journal
JMECJ

\title{
Removal of metanil yellow by batch biosorption from aqueous phase on egg membrane: Equilibrium and isotherm studies
}

\author{
Beniah Obinna Isiuku ${ }^{\mathrm{a},{ }^{*}}$ and Francis Chizoruo Ibe \\ ${ }^{a}$ Department of Chemistry, Imo State University, PMB 2000, Owerri, Imo State, Nigeria Obinna Isiuku
}

\begin{abstract}
A R T I C L E I N F O
Received 25 Aug 2019

Revised form 21 Oct 2019

Accepted 17 Nov 2019

Available online 25 Dec 2019

Keywords:

Batch biosorption,

Hen egg membrane, Isotherm modeling, Metanil yellow, Physisorption
\end{abstract}

\begin{abstract}
A B S T R A C T
The biosorption of metanil yellow on hen egg membrane from aqueous solution in a batch process was investigated at $29^{\circ} \mathrm{C}$ with a view to determine the potential of the membrane in removing metanil yellow from aqueous solution. The effects of contact time, initial biosorbate concentration, biosorbent dosage and initial biosorbate $\mathrm{pH}$ were determined. Various isotherm models were used to analyze experimental data. The highest experimental equilibrium biosorption capacity obtained was $129.88 \mathrm{mg} \mathrm{g}^{-1}$. The optimum $\mathrm{pH}$ was 3 . Adsorption capacity increased with increase in initial solution concentration but decreased with increase in time. The isotherm models applied were good fits based on correlation coefficients. Flory-Huggins isotherm was the best fit $\left(\mathrm{R}^{2}=0.986\right)$. The biosorption was endothermic, good, physisorptive and spontaneous. This work shows that hen egg membrane is a potential biosorbent for the removal of metanil yellow from aqueous solution.
\end{abstract}

\section{Introduction}

The production of different kinds of chemical compounds due to rapid large-scale industrialization has created serious environmental pollution [1]. Dyes are organic compounds used for imparting color in textile, printing and paint industries. Due to their chemical structures, synthetic dyes dissolved in wastewaters are not degraded on exposure to light, chemical and biological treatments [2]. The discharge of dyes into water bodies cause immediate visible pollution and contamination

${ }^{*}$ Corresponding Author: Beniah Obinna Isiuku

Email: obinnabisiuku@yahoo.com

https://doi.org/10.24200/amecj.v2.i04.78 due to their organic and toxic nature. The presence of dyes in water bodies hinders photosynthesis [3]. Dye_wastewaters_discharged from textile and dyestuff industries into water bodies generate growing public concern due to their toxicity and carcinogenicity [4]. Hen egg membrane comprises majorly of two parts: the egg membrane made up of protein fibers that are interwoven and spherical masses, and the calcified eggshell composed of interstitial calcite or calcium carbonate crystals [5]. Hen egg membrane is situated on the inner surface of the eggshell. The membrane is a dual membrane with structure that can be said to be an intricate 
lattice meshwork of large and small fibers which interlock with each other to form a tenacious sheath. Apart from collagen, egg membrane contains polysaccharides [6]. Due to the polysaccharide and collagen contents which provide hydroxyl, amine and sulphonic functional groups on which adsorbate particles can stick, hen egg membrane exhibits good biosorption properties [7]. Eggs from hens are used in large quantities by food manufacturers, hatcheries, hotels and restaurants and the shells are disposed of as waste [8]. Metanil yellow is a water-soluble azo dye used in the beverages, leather, paper, and textile industries. It is also used as a stain and as an indicator in acidbase titrations [9]. Metanil yellow has detrimental health effects on humans [10]. It is toxic if absorbed through the skin, respiratory and intestinal tract and may act as a skin, eye or respiratory tract irritant. It is harmful when swallowed or inhaled and may be carcinogenic under long time exposure $[11,12]$. Different methods have been developed to remove synthetic dyes from wastewater in order to reduce their impact on the environment. The methods include floatation, electro-coagulation, ozonation, photo-catalytic degradation, chemical oxidation, precipitation, filtration and adsorption [3, 13]. Adsorption is superior to the other mentioned methods due its low cost, flexibility, simplicity of design, ease of operation and insensitivity to toxic pollutants [13]. Biosorption is the type of adsorption whereby contaminants in air or water are removed using natural biological materials. Adsorption is mostly applied in cases where the contaminants do not readily undergo biological degradation and their concentrations are very low [14-17]. Batch adsorption experiments are usually done to measure the effectiveness of adsorption for removing specific adsorbates as well as to determine the maximum adsorption capacity [18]. Hen egg membrane had been used to remove metal ions and Levafix Brilliant Red E-4BA from aqueous solutions by biosorption [6]. Pramanpol and Nitayapat [8] used eggshell and egg shell containing the membrane to remove Reactive Yellow 205. Their results showed a $10-27$ fold increase in biosorption capacity due the presence of the membrane. Hassan and Salih [7] used eggshell containing the membrane to effectively remove methylene blue, a cationic dye from aqueous solution. The aim of this work was to determine the performance of hen egg membrane in the removal of metanil yellow from aqueous solution. The impacts of initial dye solution concentration, contact time, biosorbent dosage and initial solution $\mathrm{pH}$ were investigated.

\section{Experimental}

\subsection{Preparation of dye solution}

The metanil yellow (Merck, Switzerland) of $70 \%$ purity, used in this study was purchased at Onitsha, Nigeria and used directly without further treatment. The structure of metanil yellow, an anionic dye is shown in Figure 1. The stock solution was prepared by dissolving $1 \mathrm{~g}$ dye per litre solution using distilled water. Different solution concentrations (25-100 $\mathrm{mgL}^{-1}$ ) used in this work, were obtained by diluting the stock solution. $1 \mathrm{M}$ nitric acid and $1 \mathrm{M}$ sodium hydroxide solutions were used for $\mathrm{pH}$ adjustments.

\subsection{Preparation of hen egg membrane}

The hen eggshells were obtained from restaurants and hatcheries in Owerri, Imo State, Nigeria. The eggshells were washed with hot water and rinsed thrice with hot distilled water to remove odor and dirt. The eggshells were boiled for $30 \mathrm{~min}$ and cooled. While soaked, the membranes were

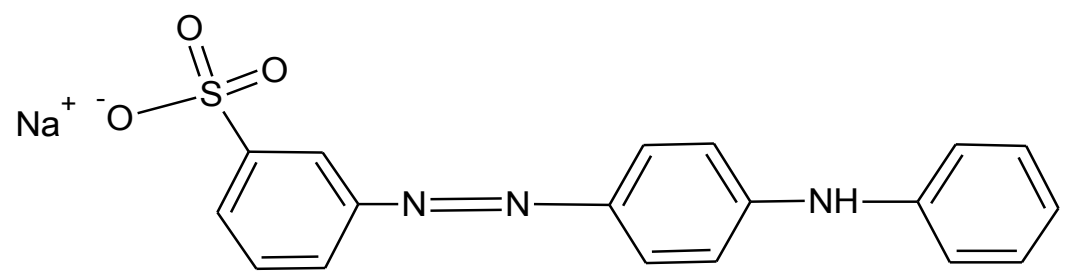

Fig. 1. The structure of metanil yellow (MY) 
peeled off, packed in a lattice and allowed for water to drain off. The membrane biomass was dried at $110^{\circ} \mathrm{C}$ in a hot air oven for $1 \mathrm{~h}$, and cooled. The dried membrane biomass was ground with a blender and sieved to obtain $0.42-0.84 \mathrm{~mm}$ size particles and packed in an airtight plastic container.

\subsection{Analysis of egg membrane}

Infra-red spectrophotometric analysis was run with a sample of the hen egg membrane with (FTIR-8400S, Shimadzu, Japan) UV/Visible spectrophotometer. Proximate analysis of the biosorbent was carried out using the method of the Association of Official Analytical Chemists (AOAC) [19]. The surface structure of the egg membrane was examined with a scanning electron microscope (SEM model Phenom Prox, Phenom World, Netherlands).

\subsection{Batch biosorption studies}

Batch biosorption of metanil yellow from aqueous solution was carried out by agitating $0.01 \mathrm{~g}$ membrane portions with $25 \mathrm{~mL}$ portions of different initial concentration of the dye solution in $50 \mathrm{~mL}$ volumetric flasks. The stoppered sample flasks were put in a water-bath shaker (SHA-C DFS KW1000BH) and agitated for $6 \mathrm{~h}$ at $29^{\circ} \mathrm{C}$ and a speed of 175rpm. A sample was collected each hour, filtered and the filtrate analyzed using UV-Visible spectrophotometer (Model 752 Shimadzu, Japan) at $\lambda_{\max } 440 \mathrm{~nm}$. Amounts of dye were absorbed on the biosorbent and determined by applying in
Equations 1 -3.

$$
\begin{aligned}
& q_{t}(m g / g)=\frac{\left(C_{o}-C_{t}\right) v}{1000 m} \\
& q_{e}(m g / g)=\frac{\left(C_{o}-C_{e}\right) v}{1000 m} \text {. } \\
& \% \text { Removal }=\frac{\left(C_{o}-C_{e}\right) 100}{C_{o}} . .
\end{aligned}
$$

\section{Results and Discussion}

\subsection{Analysis of the hen egg membrane}

Fourier Transform Infra-red spectrophotomeric analysis and proximate analysis were carried out on the egg membrane. Table 1 shows the protein, carbohydrate, fiber, and lipid contents of the biomass. Figure 2 shows the infra-red spectrum of the biosorbent. The infra-red peaks at 2341.66, $2843.17,3036.06,3255.95$, and $3618.58 \mathrm{~cm}^{-1}$ show presence of $(-\mathrm{NH})$ and $(-\mathrm{OH})$ functional groups, while $1238.34,1408.08,1519.96$, and $1658.84 \mathrm{~cm}^{-1}$ show presence of - CO-functional group. The $-\mathrm{NH}-$ and - $\mathrm{CO}$ - functional groups are present as amide group in protein fibers; the $(-\mathrm{OH})$ in carbohydrate; and $(-\mathrm{CO} ;-\mathrm{CO}-)$, in carboxylate group. [2022]. These functional groups are responsible for

Table 1. Proximate analytical data for hen egg membrane

\begin{tabular}{lr}
\hline Parameter & Value (\%) \\
\hline Ash & 8.39 \\
Moisture & 11.70 \\
Crude protein & 2.11 \\
Carbohydrate & 36.57 \\
Fiber & 27.59 \\
Lipid & 13.65 \\
\hline
\end{tabular}

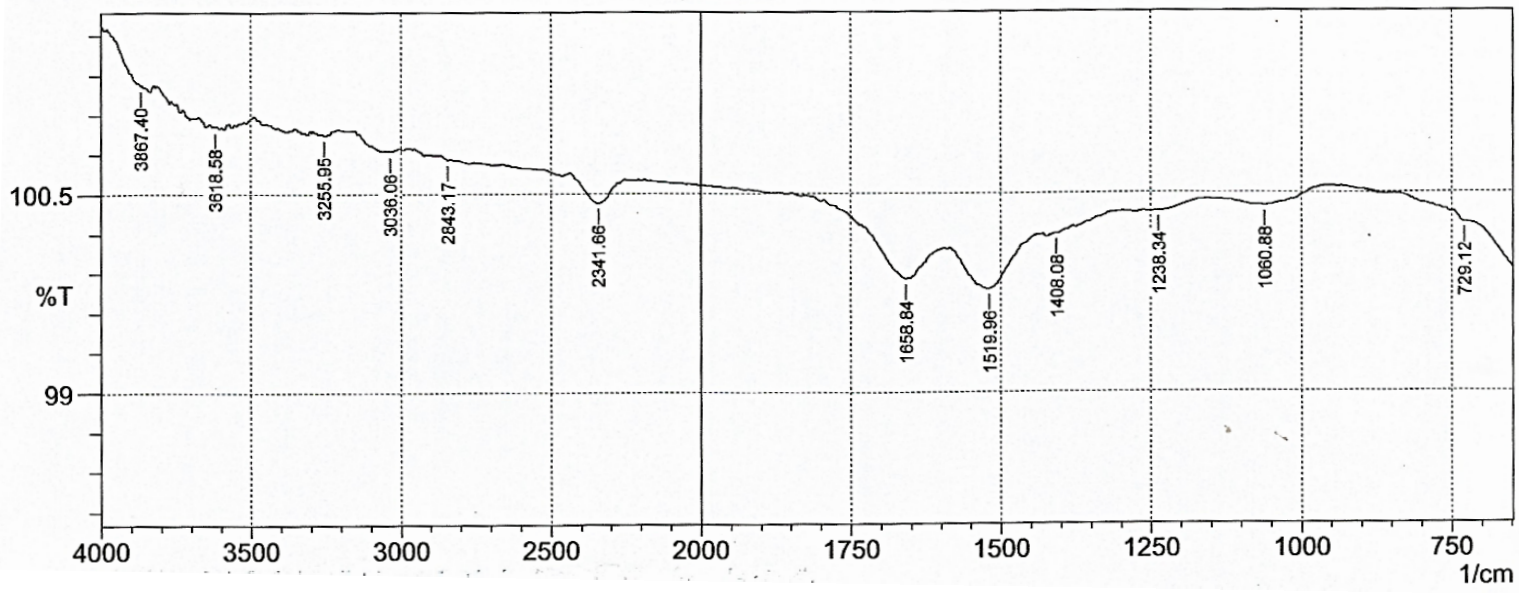

Fig. 2. FTIR spectrum of hen egg membrane 
the biosorption. Figure 3 shows the morphology of the biosorbent; it shows a well arranged lattice structure of intertwined fibres. This creates a good network of pores contributing to biosorption [6].

\subsection{Biosorption studies}

\subsubsection{Effect of initial dye concentration and con-} tact time

The effects of initial biosorbate concentration and contact time at $29^{\circ} \mathrm{C}$, agitation speed 175 $\mathrm{rpm}$ and $\mathrm{pH} 3$ are shown in Figure 4. Maximum biosorption was within the first sixty minutes for all the concentrations. Generally the equilibrium biosorption capacities were high for all the initial concentrations. However, there was appreciable decline in biosorption with time for the initial concentration $100 \mathrm{mg} / \mathrm{L}$. Results show increase in equilibrium biosorption capacity with increase in initial concentration. This agrees with the work of Njoku and Hameed [23]. The optimum time of biosorption for initial concentrations 25 and 50 $\mathrm{mg} / \mathrm{L}$ was $120 \mathrm{~min}$. For initial concentration 100 $\mathrm{mg} / \mathrm{L}$, equilibrium was not reached at $360 \mathrm{~min}$. The appreciable decrease in equilibrium biosorption capcity with time for initial concentration 100 $\mathrm{mg} / \mathrm{L}$ might be as a result of competition of the biosorbate anions for available binding sites $[24,25]$. The increase in equilibrium biosorption

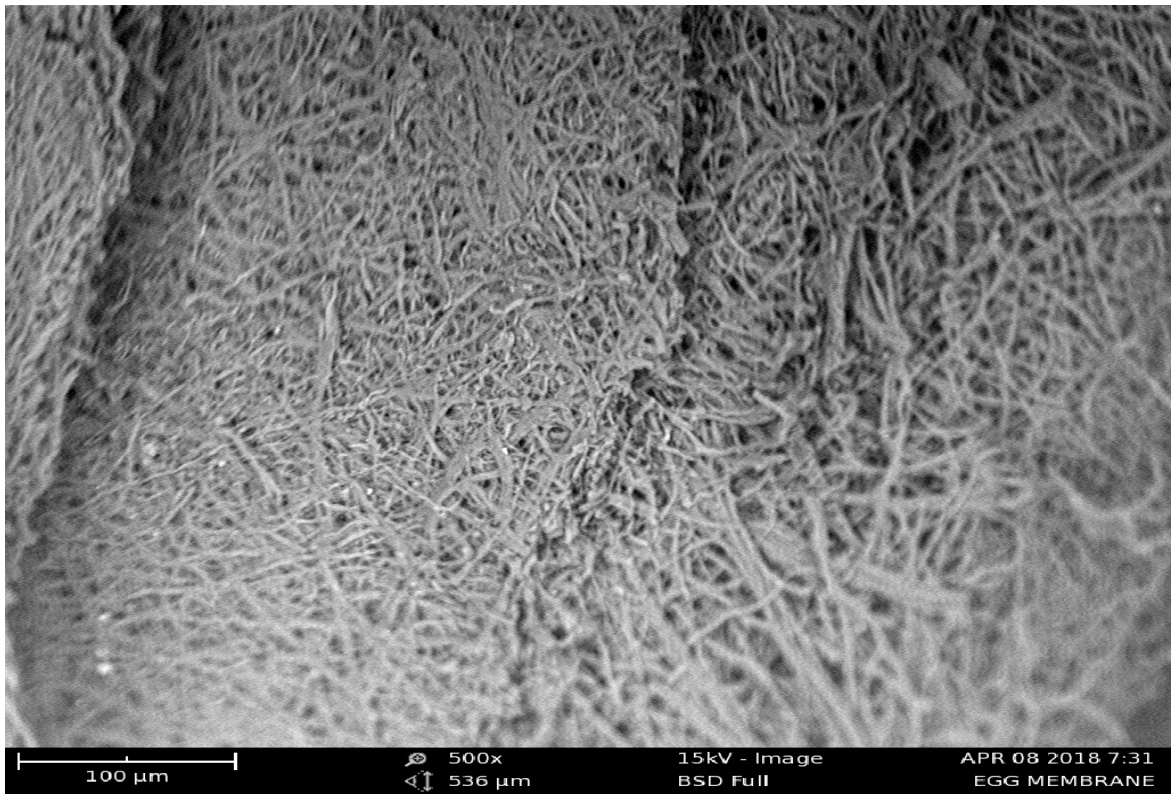

Fig. 3. Scanning electron micrograph of hen egg membrane 500x before biosorption

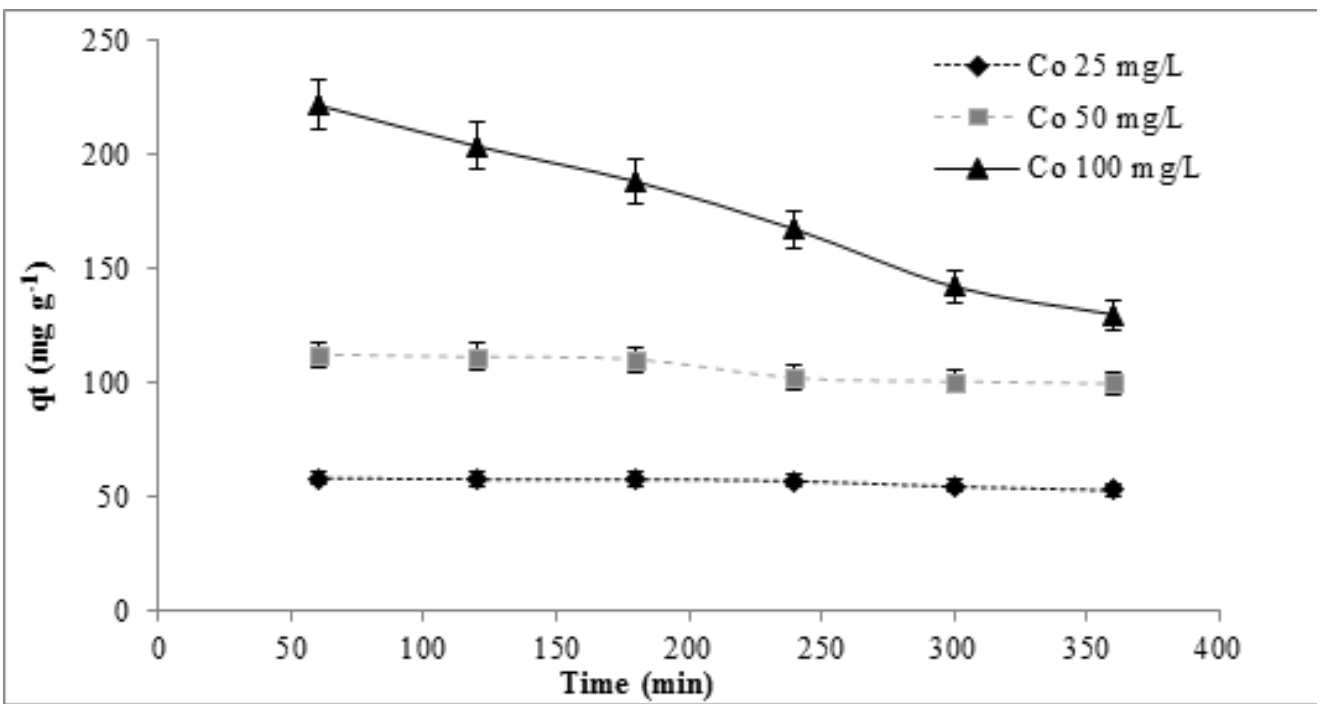

Fig. 4. Effect of initial concentration on the biosorption of metanil yellow on hen egg membrane 
capacity with increase in initial concentration is as a result of the increase in the driving force from the concentration gradient. At highest initial concentration the active sites of the egg membrane were surrounded by much more biosorbate ions leading to more enhanced biosorption [26].

\subsubsection{Effect of biosorbent dosage}

Various dosages $(0.04-1.28 \% \mathrm{w} / \mathrm{v})$ of the egg membrane were interacted with $25 \mathrm{~mL}$ portions of the dye of initial concentration $25 \mathrm{mg} / \mathrm{L}$ at $\mathrm{pH} 3$, temperature $29{ }^{\circ} \mathrm{C}$ and agitation speed of $175 \mathrm{rpm}$ for $6 \mathrm{~h}$ in order to study the effect of biosorbent dosage. The results of Figure 5 showed that equilibrium biosorption capacity decreased with increase in biosorbent dosage. This is in agreement with the work of Koumanova et al, [27]. At higher biosorbent dosage, there was a very fast superficial biosorption onto the biosorbent surface that produced a lower solute concentration in the solution than when biosorbent dosage was lower. Thus with increasing biosorbent dosage, the amount of metanil yellow biosorbed per unit mass of egg membrane reduced, hence leading to a decrease in equilibrium biosorption capacity. This is in conformity with the report of Han et al., [26]. Increasing the biosorbent dosage from $0.04-1.28 \%$ led to a decrease in $\mathrm{q}_{\mathrm{e}}$ from 54.38 to $1.80 \mathrm{mg} \mathrm{g}^{-1}$. The optimum biosorbent dosage was found to be $0.04 \%$ $(\mathrm{w} / \mathrm{v})$.

\subsubsection{Effect of initial biosorbate $p H$}

Solution $\mathrm{pH}$ affects the properties of both biosorbate and biosorbent and is therefore a very important parameter that affects biosorption in aqueous solutions [23]. The effect of initial solution $\mathrm{pH}$ on the biosorption of metanil yellow by hen egg membrane was investigated within the $\mathrm{pH}$ range 2-7 and the result is shown in Figure 6. The figure shows the highest equilibrium biosorption capacity of $29.40 \mathrm{mg} \mathrm{g}^{-1}$ for $\mathrm{pH} \mathrm{3}$, initial dye concentration $25 \mathrm{mgL}^{-1}$, biosorbent dosage $0.08 \%$ $\mathrm{w} / \mathrm{v}$, and temperature $29^{\circ} \mathrm{C}$. There was decrease in equilibrium biosorption capacity with increase in $\mathrm{pH}$. At $\mathrm{pH} 7$, there was virtually no biosorption. The $\mathrm{pH}$ values 3 was optimum for the biosorption process. The equilibrium biosorption capacity decreased from $29.40 \mathrm{mg} \mathrm{g}^{-1}$ at $\mathrm{pH} 3$ to $26.45 \mathrm{mgL}^{-1}$ at $\mathrm{pH}$ 2. The reason for the decrease was attributed to the increase in $\mathrm{H}^{+}$concentration leading to the formation of aqua complexes thereby retarding the biosorption process. This agrees with the report of Mas Haris and Sathasivam, [28]. At low pH, the carboxylate anion of the protein fiber present in

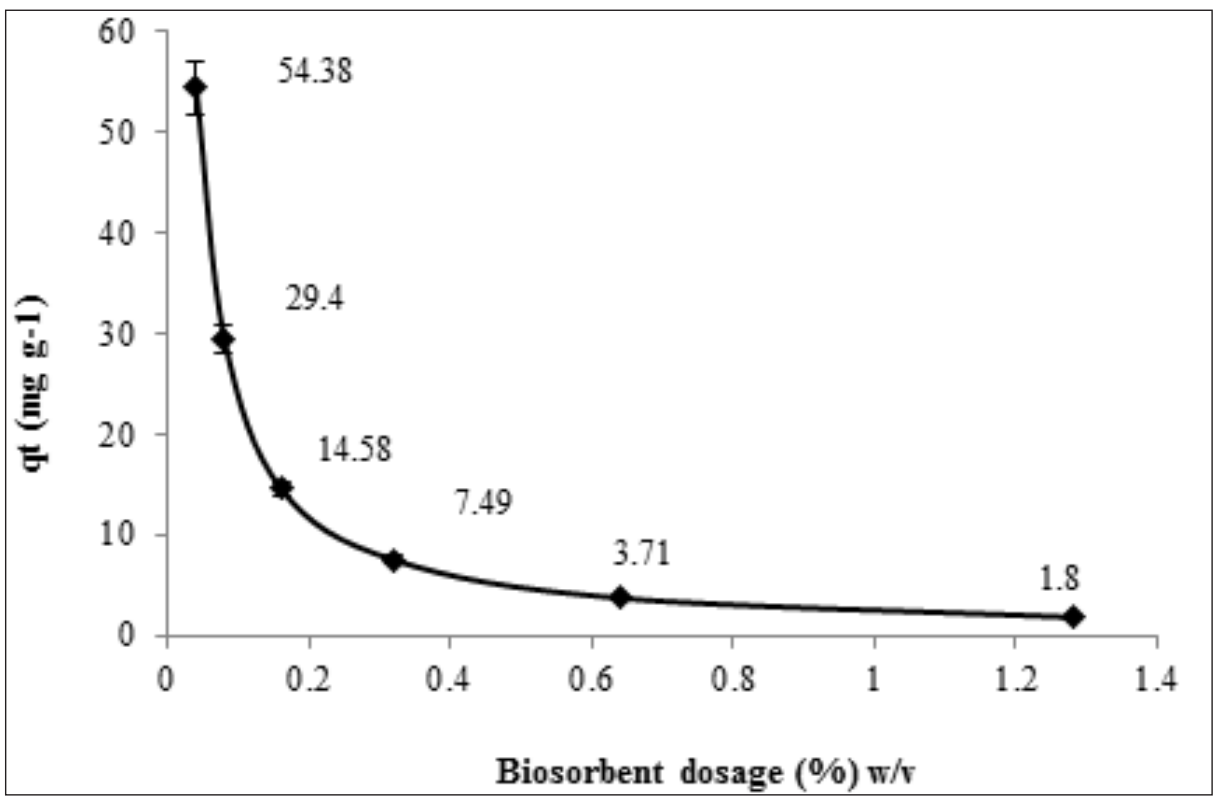

Fig. 5. Effect of adsorbent dosage on the biosorption of metanil yellow on hen egg membrane 


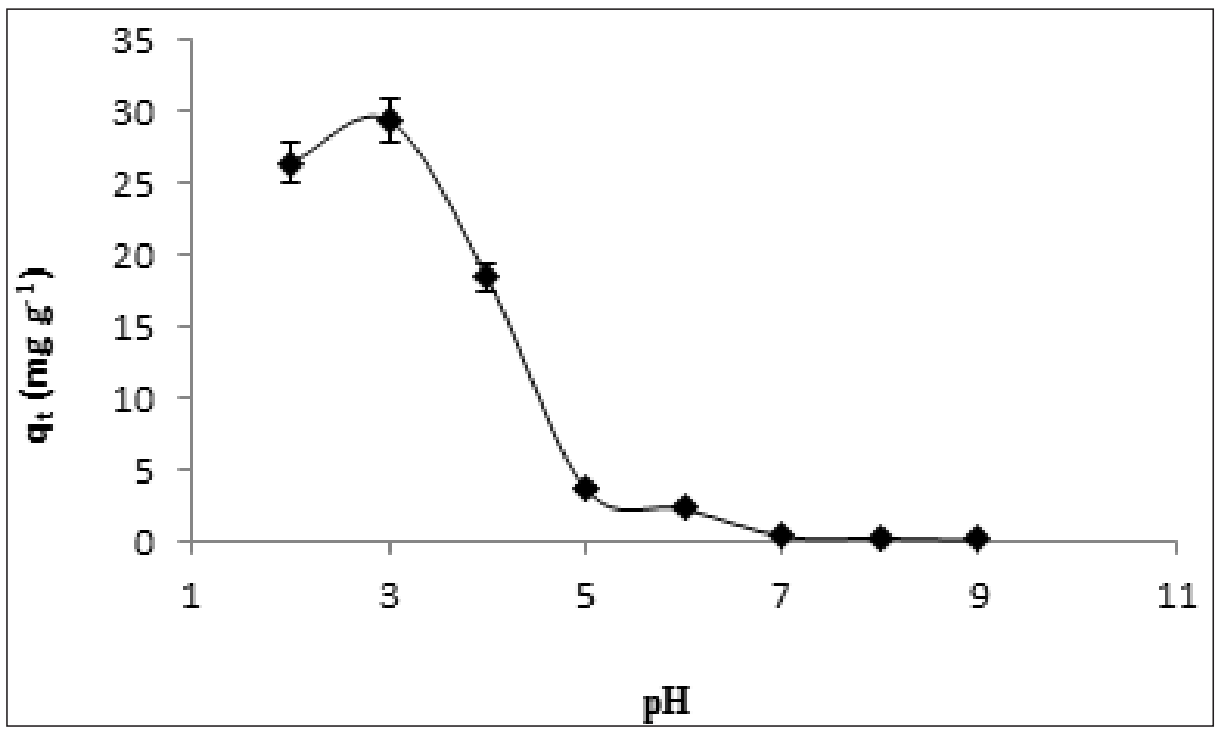

Fig. 6. Effect of initial $\mathrm{pH}$ on biosorption of metanil yellow on hen egg membrane

the membrane as part of the amino acid functional group was protonated and the amino acid existed primarily in the ammonium ion form; the oxo functional group present in the polysaccharide was also protonated. These conditions created positively charged surface on the biosorbent hence, high biosorption; as the $\mathrm{pH}$ was raised, the ammonium ion site in the protein was deprotonated, and the molecule existed as the carboxylate anion; the oxo functional group was hydrated generating hydroxyl ions which repelled the metanil yellow anions [21,29]. These conditions were responsible for poor biosorption at higher $\mathrm{pH}$ values.

\subsection{Adsorption Isotherm modeling}

An adsorption isotherm indicates how adsorbed particles distribute between the liquid phase and the solid phase when the adsorption process reaches an equilibrium state [26]. To enhance the description of an adsorption process in terms of batch equilibrium process a finite amount of adsorbent is brought into contact with various concentrations of the adsorbate. Batch equilibrium studies yield information as to the total capacity of an adsorbent for a particular material in single component systems. However, isotherms are obtained under equilibrium conditions, whereas in most adsorption treatment applications the retention time is too short for equilibrium to be attained [6].
The analysis of the isotherm data by fitting them to different isotherm models is an important step to find the suitable model that can be used for design purposes [5, 26]. An adsorption isotherm is critical in optimizing the use of adsorbents. In this study many isotherm models were used to model experimental data. The applicability of the isotherm models to the biosorption was compared by judging the correlation coefficient values.

\subsubsection{Langmuir isotherm model}

The Langmuir isotherm assumes a homogenous surface with identical sites in terms of energy for the biosorbent $[30,31]$. It is represented by Eq. 4 :

$q_{e}=\frac{q_{m} K_{L} C_{e}}{1+K_{L} C_{e}}$

The type 2 linearized Langmuir equation is given as Eq. 5:

$\frac{1}{q_{e}}=\frac{1}{K_{L} q_{m}} \frac{1}{c_{e}}+\frac{1}{q_{m}}$

A plot of $1 / q_{e}$ against $1 / C_{e}$, gave a straight line with slope $1 / \mathrm{K}_{\mathrm{L}}$ and intercept $1 / \mathrm{q}_{\mathrm{m}}$ as shown in Figure 7. Table 2 shows the model parameters $\left(K_{L}, q_{m}\right.$ and $\left.R_{L}\right) . R^{2}$ value $(0.977)$ shows that the experimental results fitted well into the Langmuir isotherm model. The essential characteristics of the Langmuir isotherm can be expressed in terms of a dimensionless constant, the Hall separation factor $R_{L}[32]$ expressed as Eq. 6: 
$R_{L}=\frac{1}{1+K_{L} C_{o m}}$

The value of $R_{L}$ indicates the type of isotherm to be either favorable $\left(0<\mathrm{R}_{\mathrm{L}}<1\right)$, unfavorable $\left(\mathrm{R}_{\mathrm{L}}>1\right)$, linear $\left(R_{L}=1\right)$ or irreversible $\left(R_{L}=0\right)$. $R_{L}$ value was found to be 0.314 . The result shows the isotherm to be favorable. The Langmuir constant $\mathrm{K}_{\mathrm{L}}$ was used to determine the spontaneity of the adsorption by calculating the Gibbs free energy (33) applying Eq. 7:

$\Delta G_{\text {ads }}^{o}=-R T\left(\operatorname{In} K_{L}+4.02\right)$

The free energy value $\left(-5.009 \mathrm{~kJ} \mathrm{~mol}^{-1}\right)$ shows that the process was spontaneous.

\subsubsection{Freundlich isotherm model}

The Freundlich isotherm model is empirical. Assumptions made in applying this model are that, multilayer adsorption occurs on a heterogeneous adsorbent surface, and that the concentration of the adsorbate on adsorbent increases infinitely with increase in the concentration of the adsorbate [34]. The adsorbent surface has unequal available sites with different energies of adsorption [35]. It does not predict any saturation of the adsorbent by the adsorbate [30]. The Freundlich model is mathematically expressed as Eq. 8:

$q_{e}=K_{F} C_{e}^{1 / n}$

Its linear logarithmic form [31] is Eq. 9:

$$
I n q_{e}=\operatorname{In} K_{F}+\frac{1}{n} \operatorname{In} C_{e}
$$

A plot of In $\mathrm{q}_{\mathrm{e}}$ against In $\mathrm{C}_{\mathrm{e}}$, gave a straight line, with slope $1 / \mathrm{n}$, and intercept In $\mathrm{K}_{\mathrm{F}}$.

$\mathrm{K}_{\mathrm{F}}$ is the adsorption or distribution coefficient and represents the quantity of dye adsorbed onto the membrane for a unit equilibrium concentration. The mechanism and the rate of adsorption are functions of $1 / \mathrm{n}$ and $\mathrm{K}_{\mathrm{F}}$. For a good adsorbent, 0.2 $<1 / \mathrm{n}<0.8$, while a smaller value of $1 / \mathrm{n}$ indicates better adsorption and formation of stronger bond between the adsorbate and adsorbent [36]. The plot of In $\mathrm{q}_{\mathrm{e}}$ against In $\mathrm{C}_{\mathrm{e}}$ (Fig.8) gave values of $1 / \mathrm{n}, \mathrm{n}$, $\mathrm{K}_{\mathrm{F}}$ and $\mathrm{R}^{2}$ as shown in Table 2 . The $1 / \mathrm{n}$ value $(0.34$ $<1)$ shows that the biosorption was physisorptive; $\mathrm{n}(2.941)>1$ shows that the biosorption was good
Table 2. Isotherm parameters for batch biosorption of of metanil yellow on egg membrane at $29^{\circ} \mathrm{C}$

\begin{tabular}{|c|c|c|}
\hline Model & Parameter & Value \\
\hline \multirow[t]{6}{*}{ Langmuir } & $\mathrm{q}_{\mathrm{m}}\left(\mathrm{mgg}^{-1}\right)$ & 129.880 \\
\hline & $\mathrm{q}_{\text {expt }}\left(\mathrm{mgg}^{-1}\right)$ & 158.730 \\
\hline & $\mathrm{K}_{\mathrm{L}}\left(\mathrm{mgL}^{-1}\right)$ & 0.132 \\
\hline & $\mathrm{R}_{\mathrm{L}}$ & 0.070 \\
\hline & $\mathrm{R}^{2}$ & 0.977 \\
\hline & $\Delta \mathrm{G}_{\text {ads }}^{\mathrm{o}}\left(\mathrm{kJ} \mathrm{mol}^{-1}\right)$ & -5.009 \\
\hline \multirow[t]{4}{*}{ Freundlich } & $1 / \mathrm{n}$ & 0.34 \\
\hline & $\mathrm{n}$ & 2.941 \\
\hline & $\mathrm{K}_{\mathrm{F}}\left[\mathrm{mgg}^{-1}(\mathrm{~L} / \mathrm{mg})^{-1 / \mathrm{n}}\right]$ & 37.487 \\
\hline & $\mathrm{R}^{2}$ & 0.872 \\
\hline \multirow[t]{4}{*}{ Temkin } & $\mathrm{B}\left(\mathrm{J} \mathrm{mol}^{-1}\right)$ & 29.525 \\
\hline & $\mathrm{b}_{\mathrm{T}}(\mathrm{J} / \mathrm{mol} / \mathrm{K})$ & 85.041 \\
\hline & $\mathrm{A}_{\mathrm{T}}\left(\mathrm{L} \mathrm{g}^{-1}\right)$ & 3.025 \\
\hline & $\mathrm{R}^{2}$ & 0.935 \\
\hline \multirow{4}{*}{$\begin{array}{l}\text { Dubinin- } \\
\text { Radushkevich }\end{array}$} & $\mathrm{q}_{\mathrm{m}}\left(\mathrm{mg} \mathrm{g}^{-1}\right)$ & 123.273 \\
\hline & $\mathrm{R}^{2}$ & 3 \\
\hline & $\mathrm{E}\left(\mathrm{J} \mathrm{mol}^{-1}\right)$ & 408.248 \\
\hline & $\mathrm{R}^{2}$ & 0.98 \\
\hline \multirow[t]{3}{*}{ Elovich } & $\mathrm{q}_{\mathrm{m}}\left(\mathrm{mg} \mathrm{g}^{-1}\right)$ & 50.505 \\
\hline & $\mathrm{K}_{\mathrm{E}}$ & 0.912 \\
\hline & $\mathrm{R}^{2}$ & 0.809 \\
\hline \multirow[t]{3}{*}{ Harkin-Jura } & $\mathrm{A}_{\mathrm{HJ}}\left(\mathrm{g}^{2} \mathrm{~L}^{-1}\right)$ & 3333.33 \\
\hline & $\mathrm{B}_{\mathrm{HJ}}\left(\mathrm{mg}^{2} \mathrm{~L}^{-1}\right)$ & 1.667 \\
\hline & $\mathrm{R}^{2}$ & 0.743 \\
\hline \multirow[t]{3}{*}{ Halsey } & $\mathrm{n}_{\mathrm{H}}$ & 0.034 \\
\hline & $\mathrm{K}_{\mathrm{H}}\left(\mathrm{mg} \mathrm{L}^{-1}\right)$ & 3.025 \\
\hline & $\mathrm{R}^{2}$ & 0.935 \\
\hline \multirow[t]{4}{*}{ Flory-Huggins } & $\mathrm{n}_{\mathrm{FH}}$ & 2.551 \\
\hline & $\mathrm{K}_{\mathrm{FH}}\left(\mathrm{L} \mathrm{mol}^{-1}\right)$ & 616.464 \\
\hline & $\Delta \mathrm{G}^{\mathrm{o}}{ }_{\mathrm{ads}}\left(\mathrm{kJ} \mathrm{mol}^{-1}\right)$ & -16.13 \\
\hline & $\mathrm{R}^{2}$ & 0.986 \\
\hline
\end{tabular}

[34]. The $\mathrm{R}^{2}$ value (0.872) shows that Freundlich isotherm model simulated experimental data well.

\subsubsection{Temkin isotherm model}

The Temkin model presumes that the heat of 

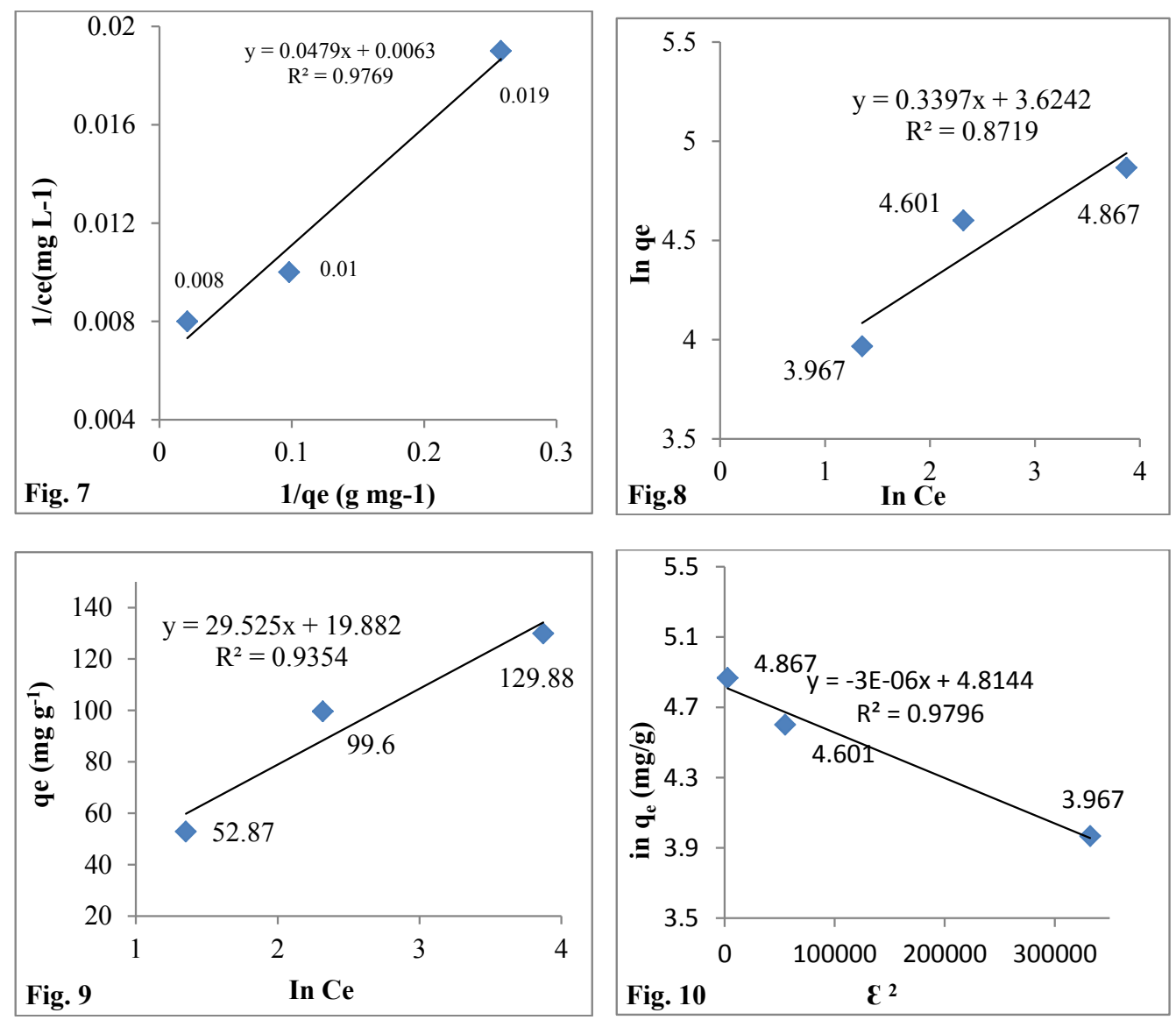

Fig. 7-10. The isotherm plot for biosorption of metanil yellow on hen egg membrane: Langmuir (Fig. 7), Freundlich (Fig.8), Temkin isotherm (Fig.9) and Dubinin-Radushkevich (Fig. 10)

adsorption of adsorbate particles in the layer decreases linearly with coverage with consideration of the effects of indirect adsorbent-adsorbate interaction, and adsorption process is characterized by a uniform distribution of binding energies, up to some maximum binding energy [13,37]. The linear form of Temkin equation $[13,38]$ is expressed as Eq. 10:

$$
\begin{array}{r}
q_{e}=B \operatorname{BIn} A+B \operatorname{In} C_{e} \\
B=R T / b_{T}
\end{array}
$$

A plot of $\mathrm{q}_{e}$ against $\operatorname{In~}_{e}$ (Fig. 9) gave a straight line with slope $\mathrm{B}$ and intercepts $\mathrm{B}$ In $\mathrm{A}$. The $\mathrm{B}, \mathrm{A}, \mathrm{b}_{\mathrm{T}}$ and $\mathrm{R}^{2}$ values are shown in Table 2. The correlation coefficient $\mathrm{R}^{2}(0.935)$ shows that the Temkin model is a good fit for simulating experimental data.

\subsubsection{Dubinin-Radushkevich isotherm model}

This model is applied in estimating the characteristic porosity of an adsorbent and the apparent adsorption energy. The model neither assumes homogenous adsorbent surface nor a constant adsorption potential as the Langmuir model [32]. The model equation is expressed a Eq.12:

$q_{e}=q_{m} e^{-B_{D} \varepsilon^{2}}$

The linearized logarithmic expression [39] of Eq.12 is Eq.13:

$$
\begin{gathered}
\operatorname{In} q_{e}=\operatorname{In} q_{m}-B_{D} \varepsilon^{2} \\
\varepsilon=R T \operatorname{In}\left[1+\left(1 / C_{e}\right)\right.
\end{gathered}
$$

A plot of $\ln \mathrm{q}_{\mathrm{e}}$ against $\varepsilon^{2}$ (Fig. 10) gave a straight line with slope $B_{D}$ and intercept $\ln \mathrm{q}_{\mathrm{m}}$. The values of $\mathrm{q}_{\mathrm{D}}$ and $\mathrm{B}_{\mathrm{D}}$ are in Table 2 .

The free energy of adsorption $\mathrm{E}(\mathrm{J} / \mathrm{mol})$ is related to the porosity factor $B_{D}$ by Eq. 15 :

$E=1 /\left(\sqrt{2 B_{D}}\right)$

E values less than $8 \mathrm{~kJ} / \mathrm{mol}$ indicate physisorption [32]. The value of $E$ in this work was $0.408 \mathrm{~kJ} / \mathrm{mol}$ showing physisorption. Positive $\mathrm{E}$ values show that the adsorption was endothermic and that higher 
temperatures would favor the adsorption [40]. $B_{D}\left(3 \times 10^{-6} \mathrm{~mol}^{2} / \mathrm{J}^{2}\right)$ is less than unity, indicating microporous adsorbent surface [41] and that the adsorbent may require less number of cycles to reduce the concentration of the adsorbate below regulatory levels [42].

\subsubsection{Elovich isotherm}

The Elovich isotherm model [43] was originally designed to describe chemisorptions of gas on solids [44]. The model assumes that there is exponential increase in adsorption sites with the adsorption process showing multilayer adsorption [45]. The Elovich isotherm model is expressed as Eq. 16:

$$
q_{e} / q_{m}=K_{E} C_{e} \exp \left(q_{e} / q_{m}\right) \text {. }
$$

The linear logarithmic form of Eq. 16 is Eq. 17:

$$
\operatorname{In}\left(q_{e} / C_{e}\right)=\operatorname{In}\left(K_{E} q_{m}\right)-q_{e} / q_{m}
$$

A plot of In $\left(\mathrm{q}_{\mathrm{e}} / \mathrm{C}_{\mathrm{e}}\right)$ versus $\mathrm{q}_{\mathrm{e}}$ (Fig. 11) gave a straight line with slope $1 / \mathrm{q}_{\mathrm{m}}$ and intercept $\operatorname{In}\left(\mathrm{K}_{\mathrm{E}} \mathrm{q}_{\mathrm{m}}\right)$ from which $\mathrm{K}_{\mathrm{E}}$ and $\mathrm{q}_{\mathrm{m}}$ were calculated. Table 2 shows the parameters $\mathrm{K}_{E}, \mathrm{q}_{\mathrm{m}}$ and $\mathrm{R}^{2}$. The $\mathrm{R}^{2}$ value (0.809) proves the Elovich model a good fit for experimental data.

\subsubsection{Harkin-Jura isotherm}

In the application of Harkin-Jura isotherm model, it is assumed that the adsorbent surface is heterogeneous in pore distribution and that adsorption is multilayer [43]. The model is expressed as Eq. 18:

$$
1 / q_{e}^{2}=\left(B_{H J} / A_{H J}\right)-\left(1 / A_{H J}\right) \log C_{e}
$$

A plot of $1 / \mathrm{q}_{\mathrm{e}}^{2}$ against $\log \mathrm{C}_{\mathrm{e}}$ (Fig. 12) gave a straight line with slope $1 / \mathrm{A}_{\mathrm{HJ}}$ and intercept $\mathrm{B}_{\mathrm{HJ}} / \mathrm{A}_{\mathrm{HJ}}$. The values of $\mathrm{A}_{\mathrm{HJ}}$ and $\mathrm{B}_{\mathrm{HJ}}$ are shown in Table 2. The $R^{2}$ value (0.743) shows that this model is a good fit for experimental data.

\subsubsection{Halsey isotherm}

The Halsey isotherm model is applied in measuring multilayer adsorption at a relatively large distance from the adsorbent surface [43]. This model is expressed as Eq. 19:

$q_{e}=\left(1 / n_{H}\right) \operatorname{In} K_{H}-\left(1 / n_{H}\right) \operatorname{In} C_{e}$

A plot of $\mathrm{q}_{\mathrm{e}}$ versus In $\mathrm{C}_{\mathrm{e}}$ (Fig. 13) gave a straight line with slope $1 / \mathrm{n}_{\mathrm{H}}$ and intercept $1 / \mathrm{n}_{\mathrm{H}} \mathrm{InK}_{\mathrm{H}}$. The values of $n_{H}$ and $K_{H}$ are in Table 2. The $R^{2}$ value (0.935) shows that the model is a good fit for experimental data.

\subsubsection{Flory-Huggins isotherm}

The relationship between behavior of the surface of the adsorbent and adsorption in terms of surface coverage is expressed applying the Flory-Huggins isotherm model [46]. The isotherm model is expressed as Eq. 20:

$$
\begin{aligned}
\operatorname{In}\left(\theta / C_{e}\right) & =\operatorname{In} K_{F H}+n_{F H} \operatorname{In}(1-\theta) \\
\theta & =1-\left(C_{e} / C_{o}\right)
\end{aligned}
$$

A plot of In $\left(\theta / \mathrm{C}_{\mathrm{e}}\right)$ versus In (1- $\left.\theta\right)$ (Fig. 14) gave a straight line with slope $\mathrm{nFH}$ and intercept $\mathrm{In}_{\mathrm{FH}}$. The values of $\mathrm{K}_{\mathrm{FH}}$ and $\mathrm{n}_{\mathrm{FH}}$ are in Table 2. The $\mathrm{R}^{2}$ value (0.986) shows that Flory-Huggins isotherm model is a good fit for the biosorption experimental data. The Gibbs free energy was calculated applying $\mathrm{K}_{\mathrm{FH}}$ according to Eq. 22:

$\Delta G_{\text {ads }}^{o}=-R T \operatorname{In} K_{F H}$

The magnitude of the free energy value $(16.13 \mathrm{~kJ} /$ $\mathrm{mol}$ ), which is lower than $20 \mathrm{~kJ} / \mathrm{mol}$ shows that the biosorption was physisorptive. The negative value of $\Delta \mathrm{G}_{\text {ads }}^{\mathrm{o}}$ shows that the process was spontaneous.

\section{Conclusions}

Hen egg membrane was successfully applied in the removal of metanil yellow from aqueous solution by batch biosorption. Experimental equilibrium data were simulated with Langmuir, Freundlich, Temkin, Dubinin-Radushkevich. Elovich, Harkin Jura, Halsey and Flory Huggins isotherms. Correlation coefficient values show that the FloryHuggins isotherm model analyzed experimental data most while the Harkin-Jura model was the least good fit. Results show that the biosorption was endothermic, good, physisorptive and spontaneous. Egg membrane is a good adsorbent for removing metanil yellow from aqueous phase. 

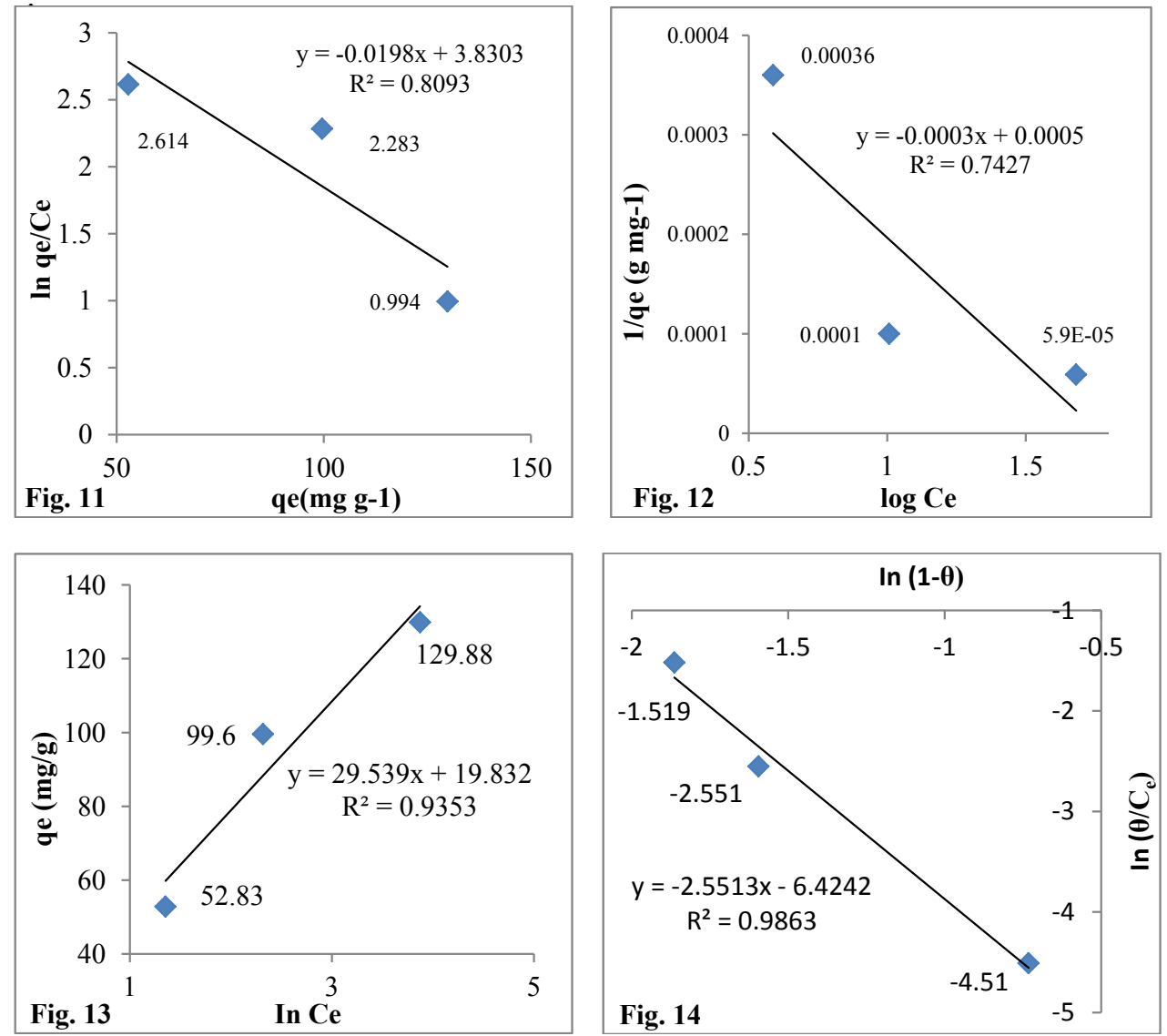

Fig. 11-14. The isotherm plot for biosorption of metanil yellow on hen egg membrane: Elovich (Fig. 11), Harkin-Jura (Fig. 12), Halsey (Fig. 13) and Flory-Huggins (Fig. 14)

\section{Glossary}

$\mathrm{A}_{\mathrm{HJ}}\left(\mathrm{g}^{2} \mathrm{~L}^{-1}\right)$ Harkin-Jura isotherm parameter

$\mathrm{A}_{\mathrm{T}}\left(\mathrm{L} \mathrm{g}^{-1}\right)$ Temkin constant corresponding to the maximum binding energy

$\mathrm{B}\left(\mathrm{J} \mathrm{mol}^{-1}\right)$ Temkin constant related to the heat of adsorption

$\mathrm{B}_{\mathrm{D}}\left(\mathrm{mol}^{2} \mathrm{~J}^{-2}\right)$ Dubinin-Radushkevich constant related to average free energy per mole of adsorbate

$\mathrm{B}_{\mathrm{HJ}}\left(\mathrm{mg}^{2} \mathrm{~L}^{-1}\right)$ Harkin-Jura isotherm model constant $\mathrm{b}_{\mathrm{T}}(\mathrm{J} / \mathrm{mol} / \mathrm{K})$ Temkin isotherm constant related to heat of adsorption, showing whether the process is endothermic or exothermic

$\mathrm{C}_{\mathrm{e}}\left(\mathrm{mg} \mathrm{L}^{-1}\right)$ Equilibrium un-adsorbed adsorbate concentration

$\mathrm{C}_{\mathrm{o}}\left(\mathrm{mg} \mathrm{L}^{-1}\right)$ Initial adsorbate concentration

$\mathrm{C}_{\mathrm{om}}\left(\mathrm{mg} \mathrm{L}^{-1}\right)$ Maximum initial concentration

$\mathrm{C}_{\mathrm{t}}\left(\mathrm{mg} \mathrm{L}^{-1}\right)$ Un-adsorbed adsorbate concentration at time $\mathrm{t}$

$\mathrm{E}\left(\mathrm{kJ} \mathrm{mol}^{-1}\right)$ Dubinin-Radushkevich isotherm model average energy of adsorption
$\mathrm{K}_{\mathrm{E}}$ Elovich isotherm constant

$\mathrm{K}_{\mathrm{F}}\left(\mathrm{mg} \mathrm{g}^{-1}(\mathrm{~L} / \mathrm{mg})^{-1 / n}\right]$ Freundlich isotherm model adsorption or distribution coefficient

$\mathrm{K}_{\mathrm{FH}}\left(\mathrm{L} \mathrm{mol}^{-1}\right)$ Flory-Huggins equilibrium constant $\mathrm{k}_{\mathrm{H}}\left(\mathrm{mg} \mathrm{L}^{-1}\right)$ Halsey isotherm model constant $\mathrm{K}_{\mathrm{L}}\left(\mathrm{L} \mathrm{mg}^{-1}\right)$ Langmuir constant related to the affinity of the binding sites and energy of adsorption $\mathrm{m}(\mathrm{g})$ mass of adsorbent

$1 / n_{\mathrm{F}}$ Freundlich constant indicating adsorption intensity and degree of heterogeneity of adsorbent surface

$\mathrm{n}_{\mathrm{F}}$ Freundlich isotherm model constant

$\mathrm{n}_{\mathrm{FH}}$ Flory-Huggins constant indicating number of adsorbate particles occupying adsorption sites

$\mathrm{n}_{\mathrm{H}}$ Halsey isotherm exponent

$\mathrm{q}_{\mathrm{D}}\left(\mathrm{mg} \mathrm{g}^{-1}\right)$ Dubinin-Radushkevich maximum adsorption capacity

$\mathrm{q}_{\mathrm{e}}\left(\mathrm{mg} \mathrm{g}^{-1}\right)$ Equilibrium adsorption capacity

$\mathrm{q}_{\mathrm{m}}\left(\mathrm{mg} \mathrm{g}^{-1}\right)$ Equilibrium adsorption capacity for a complete monolayer

$\mathrm{q}_{\mathrm{t}}\left(\mathrm{mg} \mathrm{g}^{-1}\right)$ Adsorption capacity at time $\mathrm{t}$ 
$\mathrm{R}(\mathrm{J} / \mathrm{mol} / \mathrm{K})$ Universal gas constant

$\mathrm{R}_{\mathrm{L}}$ Hall separation factor or dimensionless constant $\mathrm{R}^{2}$ Correlation coefficient

$\mathrm{T}(\mathrm{K})$ Kelvin temperature

$\mathrm{v}(\mathrm{mL})$ Adsorbate volume

$\varepsilon\left(\mathrm{kJ} \mathrm{mol}^{-1}\right)$ Polanyi potential

$\theta$ Adsorbent surface coverage

\section{References}

[1] J. H. Li, H. Yu, Y. Luan, Metal-analysis of the copper, zinc and cadmium absorption capacities of aquatic plants in heavy metal-polluted water. Int. J. Environ. Res. Public Health, 12 (2015) 14958 - 14973. doi: 10.3390/ijerph121214959

[2] N. Gopal, M. Asaithambi , P. Sivakumar , V. Sivakumar, Continuous fixed bed adsorption studies of Rhodamine-B dye using polymer bound adsorbent. Ind. J. Chem. Technol., 23 (2016) 53 - 58.

[3] A. S. Olawale, O. A. Ajayi, M. S. Olakunle, M. T. Ityokumbul, S. S. Adefila, Preparation of phosphoric acid activated carbons from Canarium schwienfurthii nutshell and its role in methylene blue adsorption, J. Chem. Eng. Mater. Sci., 6 (2015) 9- 14.

[4] O. B. Isiuku, M. Horsfall , A. I. Spiff, Adsorption of metanil yellow on chemically-activated carbon in a packed bed column: Effect of activation reagent, J. Eng. Appl. Sci., 8 (2013) 282-289.

[5] W.T. Tsai, K. J. Hsien, H.C. Hsu, C.M. Lin, K.Y. Lin, C.H. Chiu, Utilization of ground eggshell waste as an adsorbent for the removal of dyes from aqueous solution, Bioresour. Technol., 99 (2008) 1623-1629.

[6] B. Koumanova, P. Peeva, S. J. Allen, K. A. Gallagher, M. G. Healy, Biosorption from aqueous solutions by eggshell membrane and Rhizopus oryzae: Equilibrium and kinetic studies, J. Chem. Technol. Biotechnol., 77 (2002) 539-545.

[7] A. A. Hassan, Z. A. Salih, Methylene blue removal from aqueous solution by adsorption on eggshell bed Euphrates, J. Agric. Sci., 5 (2013) 11 - 23.

[8] N. Pramanpol, N. Nitayapat, Adsorption of reactive by eggshell and its membrane, Kasetsart J. Nat. Sci., 40 (2006) 192-197.

[9] B. O. Isiuku, C. N. Nwosu, Fixed-bed adsorption of metanil yellow from aqueous solution on $\mathrm{HNO}_{3}$ treated- $\mathrm{H}_{3} \mathrm{PO}_{4}$-activated carbon from gmelina bark, Asian J. Chem., 20 (2017) 475 - 479.

[10] S. Gupta, M. Sundarrajan, K. V. K. Rao, Tumour promotion by metanil yellow and malachitle green during rat hepatocarcinogenesis associated with dysregulated expression of cell cycle regulatory proteins, Tetragon, Carcin. Mut., (2003) 301-312.

[11] R. Sivashankar, V. Sivasubramanian, A. B. Sathya, S. Pallipad, Biosorption of hazardous azo dye metanil yellow using immobilized aquatic weed. Proceedings of the International Conference on Future Trends in Structural, Civil, Environmental and Mechanical Engineering - FTCEM, 153-157, India, 2013.

[12] R. Jain, N. Sharma, K. RadhapyariRemoval of hazardous azo dye, metanil yellow from industrial wastewater using electrochemical technique, Euro, Water, 27 (2009) 43-52

[13] Z. Tong, P. Zheng, B. Bai H. Wang, Y. Suo, Adsorption performance of methyl violet via $\alpha-\mathrm{Fe}_{2} \mathrm{O}_{3} @$ porous hollow carbonaceous microspheres and its effective regeneration through a Fenton-like reaction, Catalysts, 6 (2016) 58. doi: 10.3390/catal6040058

[14] V. O. Njoku, A. A. Ayuk, E. E. Oguzie, E. N. Ejike, Biosorption of $\mathrm{Cd}$ (II) from aqueous solution by cocoa pod husk biomass: Equilibrium, kinetic and thermodynamic studies, Sep. Sci. Technol., 47 (2012) 753-761.

[15] J. L. Wang, C. Chen, Biosorbents for heavy metals removal and their future. Biotchnol. Adv., 27 (2009)195.

[16] R. Pelech, F. Milchert, M. Bartkowink, Fixedbed adsorption of chlorinated hydrocarbons from multicomponent aqueous solution onto activated carbon: Equilibrium column model, J. Colloid Interface Sci., 296 (2006) 458-464.

[17] B. Volesky, Biosorption for the next century, Hydrometallurgy, 59 (2001) 203.

[18] B. O. Isiuku, M. Horsfall, A. I. Spiff, Colour removal from a simulated methyl red wastewater by adsorption on carbon in a fixed bed, Res. J. Appl. Sci., 9 (2014) 202-207.

[19] Association of official analytical chemists (AOAC), official methods of analysis, $15^{\text {th }}$ Ed., Arlington, VA, 1990.

[20] D. H. Williams, I. Fleming, Spectroscopic methods in organic chemistry, $3^{\text {rd }} \mathrm{Ed}$., McGraw Hill book Company (UK) Ltd, pp. 49-58, 1980.

[21] I. L. Finar, Organic chemistry, vol. 1: The Fundamental Principles, 6 ${ }^{\text {th }}$ Ed., Longman Group Ltd., pp. 207, 1973.

[22] I. L. Finar, Organic chemistry, vol. 2, $5^{\text {th }}$ Ed., ELBS, Longman Group Ltd., pp. 651- 660,1975.

[23] V. O. Njoku, B. H. Hameed, Preparation and characterization of activated carbon from corncob by chemical activation with $\mathrm{H}_{3} \mathrm{PO}_{4}$ for 2 , 
4-dichlorophenoxyacetic acid adsorption. Chem. Eng. J., 173 (2011) 391-399.

[24] O. A. Ekpete, M. Horsfall, A. I. Spiff, Removal of chlorophenol from aqueous solution using fluted pumpkin and commercial activated carbon, Asian J. Nat. Appl. Sci., 1 (2010) 96- 105.

[25] A. Mahvi,A. Maleki, A. Eslami, Potential of rice husk and rice husk ash for phenol removal in aqueous systems, Amer. J. Appl. Sci., 14 (2004) 321-326.

[26] R. Han, W. Zou, W. Yu, S. Cheng, Y. Wang, J. Shi, Biosorption of methylene blue from aqueous solution by phoenix tree leaves, J. Hazard. Mater., 141 (2007) $156-162$.

[27] B. Koumanova, P. Peeva-Antova, Z. Yaneva, Adsorption of 4-chlorophenol from aqueous solution on activated carbon: Kinetic, J. University Chem. Technol. Metallurg., 40 (2005) 213-218.

[28] M-R. H. Mas Haris, K. Sathasivam, The removal of methyl red from aqueous solution using banana pseudo fibers. Amer. J. Appl. Sci., 6(2009) 1690-1700.

[29] M. Jones Jr, Organic chemistry, W. W. Norton and Company, $2^{\text {nd }}$ Ed., pp. 715, 2000.

[30] P. D. Rocha, A. S. Franca, L. S. Oliveira, Batch and column studies of phenol adsorption by an activated carbon based on acid treatment of corn cobs, IACSIT Int. J. Eng. Technol., 7 (2015) 459 - 464.

[31] M. A. Yousif, A. A. Atia, O. F. Zaid, I. A. Ibrahim, Efficient and fast adsorption of phosphates and sulphates on prepared modified cellulose, J. Dispersion Sci. Technol., 36 (2015) 1628 - 1638.

[32] O. S. Bello, T. A. Fatona, F. S. Falaye, O. M. Osuolale, V. O. Njoku, Adsorption of eosin dye from aqueous solution using groundnut hull-based activated carbon: kinetic, equilibrium and thermodynamic studies, Environ. Eng. Sci., 29 (2012) 186 - 194.

[33] I. Ismi, H. Elaidi, A. Lebkiri, A. Skalli, E.H. Rifi. Adsorption of silver $\left(\mathrm{Ag}^{+}\right)$from aqueous solution by the sodium polyacrylate form, Int. J. Adv. Res. Technol., 3 (2014) 121-127.

[34] B. O. Isiuku, C. U. Nwogu, Cationic dye (methyl violet) removal from aqueous solution by egg membrane in a batch biosorption process, Asian J. Green Chem., 3 (2019) 236-257.

[35] V. O. Njoku, C. Obi, E. E. Oguzie, A. A. Ayuk, O. S. Bello, Removal of $\mathrm{Cr}$ (III) and $\mathrm{Zn}$ (II) from aqueous solutions by a Nigerian natural clay, Int J. Chem., 22(2012) 57-65.

[36] J. U. K. Oubagaranadin, Z. V. P. Murthy, P. S. Rao, Applicability of three-parameter isotherm models for the adsorption of mercury on fuller's earth and activated carbon, Ind. Chem. Eng., 49 (2007) 196 204.

[37] M. I. Temkin, V. Pyzhev, Kinetics of ammonia on promoted iron catalysts. Acta Physiochim. URSS, 12 (1940) $217-222$.

[38] M. Dutta, J. K. Basu, M. H. Faraz, N. Gautam, A. Kumar, Fixed -bed column study of textile dye Direct Blue 86 by using a composite adsorbent, Archives of Appl. Sci. Res., 4 (2012) 882 - 891.

[39] J. C. Igwe, A. A. Abia, A bioseparation process for removing heavy metals from waste using biosorbents, J. Biotechnol., 5 (2006) 1167-1179.

[40] T. A. Khan, S. Sharma, I. Ali, Adsorption of Rhodamine B dye from aqueous solution onto acid activated mango mangifera indica leaf powder: Equilibrium, kinetic and thermodynamic studies. J. Toxicol. Environ. Health Sci., 3 (2011) 286-297.

[41] U. Israel, U. M. Eduok, Biosorption of Zn from aqueous solutions using coconut (Cocus nucifera L.) coir dust, Archives Appl. Sci. Res., 4 (2012) 809-819.

[42] Z. Aksu, J. Yener, A comparative adsorption/ biosorption study of monochlorinated phenols onto various sorbents, Waste Manage., 21(2001) 695 - 702.

[43] N. Ayawei, A. Ebelegi, D. Wankasi, Modeling and interpretation of adsorption isotherms, J. Chem., (2017)1-11. https://doi.org/10.1155/2017/3039817

[44] O. Hamdaou, E. Naffrechoux, Modeling of adsorption isotherms of phenols and chlorophenols onto granular activated carbon. Part II: Models with more than two parameters. J. Hazard. Mater., 147 (2007) 401-411.

[45] M. Gubernak, W. Zapala, K. Kaczmarski, Analysis of amylbenzene adsorption equilibria on an RP-18e chromatographic column, Acta Chromatogr., 13(2003) 38-59.

[46] B.O. Isiuku, D. C. Anyanwu, C. N. Nwosu, S. C. Iroamaka, Batch adsorptive removal of metanil yellow from simulated dye wastewater using nitric acid-modified- $\mathrm{H}_{3} \mathrm{PO}_{4}$-activated carbon (NAMPAAC) from Gmelina arborea bark: equilibrium and isotherm studies, Desal. Water Treatment 70 (2017) 380-386. 